\title{
MORPHOLOGICAL FEATURES OF ZOPE, ABRAMIS BALLERUS, FROM THE MIDDLE STRETCH OF THE ODRA RIVER, POLAND
}

\author{
Jolanta SZLACHCIAK* \\ Division of Zoology, University of Warmia and Mazury, Olsztyn, Poland
}

Szlachciak J. 2005. Morphological features of zope, Abramis ballerus, from the middle stretch of the Odra River, Poland. Acta Ichthyol. Piscat. 35 (2): 93-101.

\begin{abstract}
Background. The zope (blue bream), Abramis ballerus (L., 1758), is a cyprinid fish without economic importance, and its morphology has been poorly known. The monophyly of the genus Abramis is still unclear; therefore any new contribution to the knowledge on the morphology of zope could shed a new light on the phylogeny of this group of fishes. The aim of the present study was to learn and describe meristic- and morphometric futures of zope and to compare the results with published data.

Material and methods. A total of 40 specimens of the zope, Abramis ballerus, were caught in the middle stretch of the Odra River, near the city of Głogów, western Poland, in October 2002. For each fish, 21 biometric features were measured and selected meristic features (external and internal) were determined. Cephalic sensory canals were studied and their pores were counted.

Results. The coefficient of variation for the body proportions of zope from the middle stretch of the Odra River ranged from $3.89 \%$ to $19.13 \%$ and its principal features were as follows: $D$ III 8-10; $A$ III 34-43; $P$ I 14-18; $V$ II 7-9; l.l. 62-75. It had one row of pharyngeal teeth, most frequently, in 5-5 pattern. The total number of vertebrae ranged from 46 to 48 , (mean 47.38). The preoperculo-mandibular canal (CPM) and infraorbital canal (CIO) had the highest number of pores.

Conclusion. The presently reported study shows that the sample analysed did not differ significantly from the population of the Dniepr River, although it differed significantly (in body proportions) from those of Lake Dąbie. The majority of values of meristic features did not differ significantly from those found in literature. However, there is still too little comparative material regarding internal meristic features and especially its osteology.
\end{abstract}

Key words: fish, blue bream, zope, Abramis ballerus, meristics, biometry

\section{INTRODUCTION}

Zope (blue bream), Abramis ballerus, is a cyprinid fish occurring in Europe. Zope inhabits mainly lower stretches of bigger rivers and prefers slowly running and steady waters. It is most common in waters of south-eastern Europe (Tadajewska 2000). In Poland it has sporadically been observed in rivers Brda, Drwęca, Bzura, and Warta (Rolik and Rembiszewski 1987). According to Kompowski (1991) A. ballerus used to be a rare fish in Polish waters before the Second World War. Since the mid-1960s an abundance of zope has been observed in Lake Dąbie, the Szczecin Lagoon, and the lower Odra River. Zope is not a valuable fish and has no economic importance (Tadajewska 2000).

The zope is a representative of the order Cypriniformes, family Cyprinidae, subfamily Leuciscinae (cf. Nelson 1994). Howes (1991) identified three monophyletic lineages in this subfamily: Abramin, Aspinin, and Phoxinin. The lineage Abramin consists of eight genera, four of which (Abramis, Rutilus, Chondrostoma, and Acanthobrama) occur in Western- and Eastern Europe, and do not reach central Asia. The genus Abramis accommodates 4 species: zope, Abramis ballerus (Linneaus, 1758); white bream, Abramis bjoerkna (Linnaeus, 1758); carp bream, Abramis brama (Linnaeus, 1758); and whiteeye bream, Abramis sapa (Pallas, 1814). Its monophyly remains unclear (Hensel 1978). A molecular phylogenetic study revealed that the genus Abramis is paraphyletic. Abramis ballerus and Abramis sapa are placed basal to a group of species including, among others, A. brama, A. bjoerkna, and Vimba spp. (Durand et al. 2002).

All the four species are present in Polish waters. Among them the zope is the most slender and the only planktivorous species.

There are few papers dealing with the morphological features of zope from Polish waters. Studies on this species have covered the growth rate, some meristic features, food and feeding behaviour, and parasites, in zope

\footnotetext{
* Correspondence: Dr Jolanta Szlachciak, Katedra Zoologii, Wydział Biologii, Uniwersytet Warmińsko-Mazurski, ul. Oczapowskiego 5, 10-957 Olsztyn, Poland, phone (+48) 89 523-3734, fax (+48) 89 523-3261, e-mail: jolasz@uwm.edu.pl
} 
population from Lake Dąbie (Kompowski 1971a, b, Wierzbicka 1977, Rolik 1985). Selected biometric features were analysed by Krzykawski et al. (1996). Gąsowska (1980) studied a few osteological features while looking for possible affinities between fishes of the genus Abramis and the American genus Notemigonus.

The aim of this paper was to describe morphology of zope, based on its meristic and biometric characters, with a special emphasis on the cephalic sensory canals. Another aim was to determine how different would be the morphology of zope from the middle stretch of the Odra River form other studied populations, mainly from Lake Dąbie (Odra River estuary).

\section{MATERIAL AND METHODS}

The material for the presently reported study was collected in October 2002, from the middle stretch of the Odra River, near the city of Głogów (Fig. 1). The fish were captured using gill nets, by commercial fishermen. In total 40 specimens (13 males and 27 females) were examined. For each fish 21 distances were measured, to the nearest $0.1 \mathrm{~mm}$, according to the modified cyprinid scheme developed by Brylińska (2000) (Table 1). The measurements were expressed as a percentage of the standard length (SL) and head length $(l c)$ (Strauss and Bond 1990). Due to unequal number of individuals from both sexes the differences in body proportions between males and females were not tested.

The following meristic features (external and internal) were determined: soft (branched) rays of fins: dorsal $(D)$, anal $(A)$, pectoral $(P)$, and ventral $(V)$ (two last branched dorsal and anal fin rays were counted as one); number of scales in the lateral line (l.l.), number of pharyngeal teeth $(P h F)$; number of vertebrae in different portions of the vertebral column: predorsal vertebrae $(V p d)$ (i.e. lying anteriorly from dorsal fin insertion), abdominal vertebrae $(V a)$, intermediate vertebrae $(V i)$, caudal vertebrae $(V c)$, hemal vertebrae $(V h)$ (caudal plus intermediate ones with parapophyses connected by a bridge below the hemal canal); total number of vertebrae (Vt), including the Weberian apparatus and the last complex preural-ural centrum; the number of openings of cephalic sensory canals on particular bones in the neurocranium and visceral skeleton: preoperculo-mandibular canal $(C P M)$ : dentary, articular, preopercle, opercle; supraorbital canal (CSO): frontal, parietal; supratemporal canal (CST): parietal, posttemporal; infraorbital canal $(\mathrm{CIO})$ : lacrimal, infraorbitals $2-5$, pterotic.

Internal features of fish were counted from dry skeleton preparations obtained by boiling in hot water. Pore counts were made from both the left and right side of the head; the number of canal openings of an individual bone included entry and exit.

The results of biometric and meristic characteristics were presented as range of values, arithmetic means $(\bar{x})$, standard deviations $(s)$, and coefficient of variation $(\mathrm{V}, \%)$.

\section{RESULTS}

Biometric features. Relative values of biometric features of zope are shown in Table 2. The general body

Studied biometric features of zope, Abramis ballerus

Table 1

\begin{tabular}{|c|c|c|}
\hline Symbol & English term & Latin term \\
\hline$l c$ & Lateral length of head & longitudo capitis lateralis \\
\hline $\mathrm{prO}$ & Preorbital distance & spatium praeorbitale \\
\hline$O$ & Diameter of eye & diameter oculi \\
\hline poO & Postorbital distance & spatium postorbitale \\
\hline$h c$ & Head depth & altitudo capitis \\
\hline lac & Head width & latitudo capitis \\
\hline lmd & Lower jaw (mandibular) length & longitudo mandibulae \\
\hline$S l$ & Body (standard) length & longitudo corporis \\
\hline$p D$ & Predorsal distance & distantia praedorsalis \\
\hline poD & Postdorsal distance & distantia postdorsalis \\
\hline$H$ & Maximum body depth & altitudo corporis maxima \\
\hline$h$ & Minimum body depth & altitudo corporis manima \\
\hline$l p c$ & Length of caudal peduncle & longitudo pedunculi caudalis \\
\hline laco & Body width & latitudo corporis \\
\hline$l P$ & Pectoral fin length & longitudo $\mathrm{P}$ \\
\hline$l V$ & Ventral fin length & longitudo $\mathrm{V}$ \\
\hline$h D$ & Dorsal fin height & altitudo D \\
\hline$h A$ & Anal fin height & altitudo $\mathrm{A}$ \\
\hline$l D_{b s}$ & Dorsal fin length & longitudo basis D \\
\hline$l A_{b s}$ & Anal fin length & longitudo basis $\mathrm{A}$ \\
\hline$P-V$ & Distance between pectoral and ventral fin & distantia $\mathrm{P}-\mathrm{V}$ \\
\hline$V-A$ & Distance between ventral and anal fin & distantia $\mathrm{V}-\mathrm{A}$ \\
\hline
\end{tabular}


Table 2 erably larger than the head width, which was

Relative values of biometric characters $(\mathrm{mm})$ of zope, Abramis ballerus from the middle stretch of the Odra River

\begin{tabular}{|c|c|c|c|c|}
\hline & Range & $\bar{x}$ & $s$ & $\mathrm{~V}[\%]$ \\
\hline $\mathrm{SL}$ & \multicolumn{4}{|c|}{ In $\%$ of body length (SL) } \\
\hline lc & $15.7-23.8$ & 20.90 & 1.506 & 7.21 \\
\hline prO & $2.2-6.8$ & 5.50 & 1.052 & 19.13 \\
\hline $\mathrm{O}$ & $2.3-6.6$ & 5.23 & 0.916 & 17.51 \\
\hline poO & $5.3-12.7$ & 10.25 & 1.352 & 13.19 \\
\hline hc & $10.8-19.4$ & 16.80 & 1.749 & 10.41 \\
\hline lac & $7.0-12.7$ & 10.42 & 1.388 & 13.32 \\
\hline lmd & $4.5-10.5$ & 7.80 & 1.058 & 13.56 \\
\hline $\mathrm{pD}$ & $44.1-95.9$ & 54.57 & 7.406 & 13.57 \\
\hline poD & $33.8-81.0$ & 42.16 & 6.890 & 16.34 \\
\hline $\mathrm{H}$ & $30.0-39.1$ & 33.21 & 2.061 & 6.21 \\
\hline $\mathrm{h}$ & $4.2-9.9$ & 7.85 & 1.073 & 13.67 \\
\hline $1 \mathrm{pc}$ & $6.3-13.7$ & 11.27 & 1.573 & 13.96 \\
\hline $1 \mathrm{P}$ & $15.5-21.5$ & 19.10 & 1.443 & 7.56 \\
\hline 1V & $12.5-18.4$ & 15.69 & 1.290 & 8.22 \\
\hline $\mathrm{hD}$ & $18.9-26.8$ & 22.90 & 1.608 & 7.02 \\
\hline hA & $10.9-19.7$ & 15.91 & 1.548 & 9.73 \\
\hline $1 \mathrm{D}_{\mathrm{bs}}$ & $6.1-12.4$ & 9.23 & 1.361 & 14.75 \\
\hline $1 A_{b s}$ & $26.3-41.1$ & 34.88 & 3.055 & 8.76 \\
\hline $\mathrm{P}-\mathrm{V}$ & $12.9-24.9$ & 19.49 & 2.591 & 13.29 \\
\hline \multirow[t]{2}{*}{$\mathrm{V}-\mathrm{A}$} & $12.5-22.7$ & 18.57 & 2.408 & 12.97 \\
\hline & \multicolumn{4}{|c|}{ In $\%$ of head length (lc) } \\
\hline prO & $12.5-31.7$ & 26.20 & 4.453 & 16.97 \\
\hline $\mathrm{O}$ & $12.6-31.5$ & 24.97 & 3.989 & 15.98 \\
\hline poO & $33.5-57.3$ & 48.89 & 4.401 & 9.00 \\
\hline hc & $67.4-95.3$ & 80.39 & 6.731 & 8.37 \\
\hline lac & $33.7-61.5$ & 49.85 & 5.803 & 11.64 \\
\hline $\operatorname{lmd}$ & $25.1-49.5$ & 37.36 & 4.702 & 12.59 \\
\hline
\end{tabular}

$\bar{x}$, mean; $s$, standard deviation; $\mathrm{V}$, coefficient of variation

shape resembles that of a carp bream but is more slender and laterally compressed. The head, which constituted $15.7 \%-23.8 \%$ of SL, was comparatively short. The head depth at nape, which was $67.4 \%-95.3 \%$ of $l c$, was consid-
$33.7 \%-61.5 \%$ of $l c$. The postorbital distance was about half of the head length. The mouth was oblique, terminal. The lower jaw length was $25.1 \%-49.5 \%$ of $l c$. The eye was relatively small; its horizontal diameter was $12.6 \%-31.5 \%$ of $l c$ (mean $25 \%$ ).

The body was moderately deep. The maximum body depth was $30.0 \%-39.1 \%$ of SL. The length of caudal peduncle was $6.3 \%-13.7 \%$ of SL, being larger than minimum body depth, which was only $4.2 \%-9.9 \%$ of SL. The predorsal distance was $44.1 \%-95.9 \%$ of SL, whilst the postdorsal distance $33.8 \%-81.0 \%$ of SL.

The anal fin had the longest base than other fins, amounting to $10.9 \%-19.7 \%$ of SL; the shortest base was measured at the dorsal fin, which was $6.1 \%-12.4 \%$ of SL. The anal fin margin was distinctly or slightly concave. The pectoral fin reached the base of the ventral fin. The distance between pectoral- and ventral fins $(\mathrm{P}-\mathrm{V})$ ranged from $12.9 \%$ to $24.3 \% \mathrm{SL}$, and between ventral- and anal fins (V-A) ranged from $12.5 \%$ to $22.7 \%$ of SL.

Meristic features. All the fish examined had 3 hard rays in the dorsal fin. The number of soft rays exhibited a high variability $(\mathrm{V}=6.52 \%)$, ranging from 8 to 10 rays but $60 \%$ of the fish had 8 soft rays (Table 3 ).

The zope has long anal fin; the number of soft rays ranged from 34 to 43 . This parameter was characterized by lower variability $(\mathrm{V}=4.42 \%)$. The mean number of soft rays in anal fin was 37.70 , but $32.5 \%$ of the analysed fish had 38 rays.

The number of soft rays in the pectoral fin ranged from 15 to 18 (mean number 16.34), with 16 and 17 being the most common results, found in $50 \%$ and $40 \%$ of the fish, respectively. The number of soft rays in the ventral fin ranged from 7 to 9 but most fish $(85 \%)$ had 8 rays. The variability of these two parameters was $4.97 \%$ and $4.12 \%$, respectively.

Scales were relatively large. Their numbers on the lateral line varied from 62 to 72 (mean 69.94). The most

Table 3

Values of external meristic characters of zope, Abramis ballerus, from the middle stretch of the Odra River

\begin{tabular}{ccrcc}
\hline Feature & Range & \multicolumn{1}{c}{$\bar{x}$} & $s$ & $\mathrm{~V}[\%]$ \\
\hline$D$ & $8-10$ & 8.43 & 0.550 & 6.52 \\
$A$ & $34-43$ & 37.70 & 1.667 & 4.42 \\
$P 1$ & $15-18$ & 16.45 & 0.876 & 5.33 \\
$P 2$ & $14-18$ & 16.23 & 0.920 & 5.67 \\
$P$ & $15-18$ & 16.34 & 0.812 & 4.97 \\
$V 1$ & $7-9$ & 8.10 & 0.379 & 4.68 \\
$V 2$ & $8-9$ & 8.15 & 0.362 & 4.44 \\
$V$ & $7.5-9$ & 8.13 & 0.335 & 4.12 \\
$l l 1$ & $63-75$ & 70.08 & 2.464 & 3.52 \\
$l l 2$ & $62-74$ & 69.80 & 2.700 & 3.87 \\
$l . l$. & $64-73$ & 69.94 & 2.234 & 3.19 \\
\hline
\end{tabular}

$\bar{x}$, mean; $s$, standard deviation; $\mathrm{V}$, coefficient of variation; numbers 1 and 2 denote left and right side of the body 
common were specimens with 70 lateral line scales on both sides of the body ( $22.5 \%$ and $25 \%$, respectively).

The zope has one row of pharyngeal teeth. In $87.5 \%$ of the fish the pattern was 5-5, and in $12.5 \%$ it was 5-4. The teeth were high, narrow, and slightly hooked.

The total number of vertebrae ranged from 46 to 48 (mean 47.38) (Table 4). In 53.8\% of the fish there were 47 vertebrae; $42.3 \%$ of the fish had 48 vertebrae, but 46 vertebrae were found only in one specimen. All the fish had 12 to 13 abdominal vertebrae (mean 12.92). In the predorsal part the most common number of vertebrae was 10 $(57.7 \%)$. The number of caudal vertebrae was 23 or 24 (mean 23.46). In $53.8 \%$ of all specimens 23 vertebrae were found; the remaining fish had 24 vertebrae.

The analysis of the number of vertebrae in different regions of the vertebral column showed that the lowest coefficient of variation, $\mathrm{V}=1.21 \%$ was found in the case of the total number of vertebrae, whilst the highest,
$\mathrm{V}=8.69 \%$, for the intermediate vertebrae (Table 4).

The pattern of the sensory cephalic canals was typical for the subfamily Leuciscinae. The preoperculo-mandibular canal $(C P M)$ featured numerous pores (Table 5).

Table 4

Number of vertebrae of zope, Abramis ballerus, from the middle stretch of the Odra River

\begin{tabular}{crccc}
\hline Feature & \multicolumn{1}{c}{$\bar{x}$} & Range & $s$ & $\mathrm{~V}(\%)$ \\
\hline$V p d$ & 9.86 & $9-11$ & 0.560 & 5.68 \\
$V a$ & 12.92 & $12-13$ & 0.272 & 2.18 \\
$V i$ & 3.96 & $3-5$ & 0.344 & 8.69 \\
$V a i$ & 16.88 & $16-17$ & 0.326 & 1.93 \\
$V c$ & 23.46 & $23-24$ & 0.508 & 2.17 \\
$V h$ & 24.88 & $24-26$ & 0.766 & 3.08 \\
$V t$ & 47.38 & $46-48$ & 0.571 & 1.21 \\
\hline
\end{tabular}

$\overline{\bar{x}}$, mean; $s$, standard deviation; $\mathrm{V}$, coefficient of variation

Table 5

Number of pores in selected bones of lateral-system canals of zope, Abramis ballerus, from the middle stretch of the Odra River

\begin{tabular}{|c|c|c|c|c|c|}
\hline Canal & Bone & Range & $\bar{x}$ & $s$ & $\mathrm{~V}[\%]$ \\
\hline \multirow{12}{*}{ 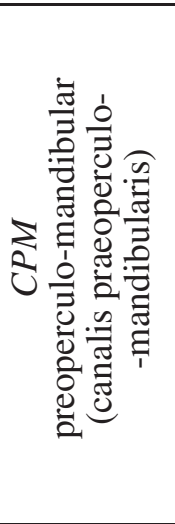 } & d-dentary & $5.5-8$ & 6.77 & 0.681 & 10.06 \\
\hline & $\mathrm{d} 1$ & $6-8$ & 6.92 & 0.796 & 11.50 \\
\hline & $\mathrm{d} 2$ & $5-8$ & 6.62 & 0.752 & 11.36 \\
\hline & a-articular & $2-3.5$ & 2.65 & 0.516 & 19.47 \\
\hline & a1 & $2-4$ & 2.63 & 0.576 & 21.90 \\
\hline & a2 & $2-4$ & 2.77 & 0.612 & 22.09 \\
\hline & p-preopercle & $9-13$ & 11.00 & 0.829 & 7.54 \\
\hline & $\mathrm{p} 1$ & $9-13$ & 10.88 & 0.927 & 8.52 \\
\hline & $\mathrm{p} 2$ & $9-13$ & 11.04 & 1.076 & 9.75 \\
\hline & o-opercle & $1.5-3$ & 2.35 & 0.419 & 17.83 \\
\hline & o1 & $1-3$ & 2.38 & 0.571 & 23.99 \\
\hline & 02 & $2-3$ & 2.31 & 0.471 & 20.39 \\
\hline \multirow{6}{*}{ 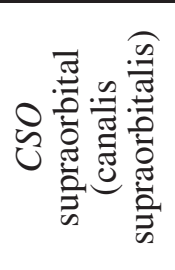 } & f-frontal & $6-10$ & 7.46 & 0.799 & 10.71 \\
\hline & $\mathrm{f} 1$ & $6-12$ & 7.50 & 1.208 & 16.11 \\
\hline & $\mathrm{f} 2$ & $6-9$ & 7.42 & 0.643 & 8.67 \\
\hline & p-parietal & $2-3$ & 2.52 & 0.386 & 15.32 \\
\hline & p1 & $2-3$ & 2.54 & 0.508 & 20.00 \\
\hline & p2 & $2-3$ & 2.50 & 0.510 & 20.44 \\
\hline \multirow{6}{*}{ 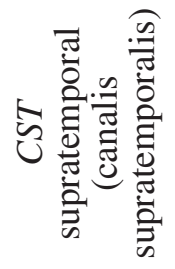 } & p-parietal & $3.5-6$ & 5.04 & 0.774 & 15.36 \\
\hline & p1 & $3-6$ & 5.07 & 0.800 & 16.0 \\
\hline & $\mathrm{p} 2$ & $3-6$ & 5.07 & 0.977 & 19.3 \\
\hline & pt-posttemporal & 2 & 2.00 & 0 & - \\
\hline & pt1 & 2 & 2.00 & 0 & - \\
\hline & $\mathrm{pt} 2$ & 2 & 2.00 & 0 & - \\
\hline \multirow{6}{*}{ 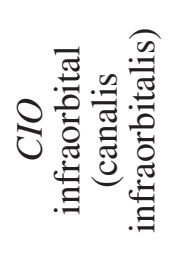 } & 1-lacrimal & $5-7$ & 6.07 & 0.634 & 10.44 \\
\hline & 11 & $5-7$ & 6.15 & 0.732 & 11.90 \\
\hline & 12 & $5-7$ & 6.00 & 0.649 & 10.82 \\
\hline & p-pterotic & $4-7$ & 4.69 & 0.664 & 14.16 \\
\hline & $\mathrm{p} 1$ & $4-7$ & 4.58 & 0.703 & 15.35 \\
\hline & $\mathrm{p} 2$ & $4-7$ & 4.81 & 0.694 & 14.43 \\
\hline
\end{tabular}

$\bar{x}$, mean; $s$, standard deviation; $\mathrm{V}$, coefficient of variation; numbers 1 and 2 denote left and right side of the body 
Their number ranged from 17 to 28 (mean 22.77). The dental bone had 5 to 8 openings, in the preopercle bone its number ranged from 9 to 13 (Fig. 2a, b). In the supraorbital canal (CSO) there were predominantly 4 pores in the nasal bone, which was small and tube-like, 6-10 and 2-3 pores in the frontal- and parietal bones respectively. In the supratemporal canal (CST) the parietal bone had 3-6 openings whereas the posttemporal bone had 2 pores in all analysed specimens. The infraorbital canal $(\mathrm{CIO})$ passed through 5 interorbital bones (Fig. 2c) and the pterotic bone. This canal joined with the temporal section of CST. On the first infraorbital bone, the lacrimal, most of the fishes analysed had 6 pores $(68.18 \%)$, its number ranging from 5 to 7 . There were 3-6 canal openings on the second infraorbital $\left(\mathrm{SO}_{2}\right), 4-8$ on third bone $\left(\mathrm{SO}_{3}\right), 2-3$ on fourth ( $\left.\mathrm{SO}_{4}\right)$, and 1-2 on the fifth ( $\left.\mathrm{SO}_{5}\right)$ one, respectively. The pterotic bone had 4-7 pores, but most often 4 or 5 . In this canal the number of pores ranged from 19 to 35 (mean 24.21).

\section{DISCUSSION}

Zope usually attains 20-25 cm SL. Bigger fish, exceeding $35 \mathrm{~cm}$, are encountered sporadically. The standard length of the fish in the analysed sample was $27.2-35.9 \mathrm{~cm}$ (mean $29.4 \mathrm{~cm}$ ). The values of standard length (SL) attained by different populations, described by other authors, are presented in Table 6.

Biometric features are strongly affected by environmental conditions. The most important role plays food supply and availability as well as water temperature (Brylińska 2000).

Compared to other populations, the analysed zope from the middle stretch of the Odra River was characterized by higher values of such parameters as preorbital distance, predorsal distance, and body depth. They had the smallest values of minimum body depth and dorsal fin length (Table 7). Rolik (1985) found in the two populations analysed (Lake Dąbie, the Dniepr River) significant differences in such characters as head length and height, interorbital and postorbital distance, height of the dorsal fin, length of the ventral- and caudal fins.

Meristic characters of an individual remain stable throughout its life span. The variability in these characters is affected by various environmental factors acting either individually, e.g. temperature (Tåning 1950) and light (Vladykov 1934) or in combination.

According to Vladykov (1934) the highest variability occurs in features which develop slowly and therefore are longer exposed to environmental conditions, e.g. fins with long bases or fins which develop in the caudal part of the body. Pectoral fins develop very early in ontogeny but need more time to be fully developed. Different numbers of fin rays reflect changing conditions during their development. Branched fin rays start to develop in the embryonic period later than vertebrae but earlier than scales and probably their number does not change in an individual along their age (Tadajewska 1980).

The mean number of dorsal fin soft rays in the zope population studied ranged from 8 to 10 (Table 8). The range was very similar to that found in other populations but their means differed significantly (Žukov 1965, Kompowski 1971a). According to Krzykawski et al. (1996) the number of soft rays in this fin is stable and amounted to 8. Similarly, the range of soft rays in anal fin was almost the same as in the populations analysed by other authors. Zope studied did not differ significantly from other populations as regards the number of soft rays in anal, pectoral and pelvic fins (Table 8).

Compared to other populations, the investigated fish had 64-73 scales in the lateral line (mean 69.90). Other authors reported other ranges: 65-73 (Žukov 1965), 68-77 (Kompowski 1971a), 67-74 (Krzykawski et al. 1996), or even 63-76 (Rolik 1985) (Table 8).

The number of pharyngeal teeth seems to be stable. The same pattern (5-5) was observed by Kompowski (1971a), Rolik (1985), Krzykawski and Gawliński (1986), Rolik and Rembiszewski (1987), and Krzykawski et al. (1996). Sporadically, other patterns were found, e.g. 5-4 (Rolik 1985, Rolik and Rembiszewski 1987, Krzykawski et al. 1996), 5-6 (Žukov 1965) or 4-4 (Aleksandrova 1966).

The number of external meristic features, which can be used in taxonomical research, is limited. In order to expand the range of such parameters one needs to include some elements of the skeleton, e.g. the vertebral column. The number of vertebrae is of special use in systematics and phylogenetic analyses of lower taxa (Dunn 1983, Howes 1987). According to Vladykov (1934) more variable are vertebrae

Comparison of standard lengths $\left(x_{9}\right)$ in samples of zope, Abramis ballerus, from different localities

\begin{tabular}{ccccc}
\hline Feature & Water body & Author & Range & $\bar{x}$ \\
\hline \multirow{5}{*}{ Standard } & Odra River & Author's data & $272-359$ & 293.62 \\
length (SL) & Dniepr River & Žukov 1965 & - & 195.6 \\
& Lake Dąbie & Kompowski 1971a & $165-310$ & - \\
& LakeDąbie & Rolik 1985 & Krzykawskiand \\
& Szczecin Lagoon & Gawliński 1986 & $84-298$ & 252.5 \\
& Lake Dąbie & Krzykawski et al. & $287-352$ & 317.8 \\
& & 1996 & \\
\hline
\end{tabular}

$\bar{x}$, mean 
Mean values of some biometric characters of zope, Abramis ballerus (in \% of standard length)

\begin{tabular}{|c|c|c|c|c|}
\hline Feature & $\begin{array}{c}\text { Present study } \\
(2005) \\
\text { Odra River }\end{array}$ & $\begin{array}{l}\text { Rolik (1985) } \\
\text { Lower Odra } \\
\text { (Lake Dąbie) }\end{array}$ & $\begin{array}{c}\text { Krzykawski et al. } \\
\text { (1996) } \\
\text { Lake Dąbie }\end{array}$ & $\begin{array}{c}\text { Žukov } \\
\text { (1965) } \\
\text { Dniepr River }\end{array}$ \\
\hline & $n=40$ & $n=55$ & $n=50$ & \\
\hline lc & $20.9 \pm 1.51$ & $20.68 \pm 0.07$ & $19.86 \pm 0.73$ & $21.41 \pm 1.05$ \\
\hline prO & $5.50 \pm 1.05$ & $5.94 \pm 0.04 *$ & $4.89 \pm 0.35^{*}$ & - \\
\hline $\mathrm{O}$ & $5.23 \pm 0.92$ & $5.27 \pm 0.03$ & $4.94 \pm 0.25^{*}$ & - \\
\hline poO & $10.25 \pm 1.35$ & $10.34 \pm 0.13$ & $10.49 \pm 0.53$ & - \\
\hline hc & $16.80 \pm 1.75$ & $17.62 \pm 0.10^{*}$ & $16.40 \pm 1.12$ & - \\
\hline lac & $10.42 \pm 1.39$ & $11.17 \pm 0.07^{*}$ & $10.15 \pm 0.89$ & - \\
\hline $\mathrm{pD}$ & $54.57 \pm 7.41$ & $51.98 \pm 0.13^{*}$ & $51.51 \pm 1.64^{*}$ & $52.07 \pm 1.70 *$ \\
\hline poD & $42.16 \pm 6.89$ & $42.14 \pm 0.14$ & $40.66 \pm 1.38$ & $40.80 \pm 1.77$ \\
\hline $\mathrm{H}$ & $33.21 \pm 2.06$ & $32.28 \pm 0.18 *$ & $34.68 \pm 1.25 *$ & $31.10 \pm 1.66^{*}$ \\
\hline $\mathrm{h}$ & $7.85 \pm 1.07$ & - & $8.77 \pm 0.43 *$ & $8.37 \pm 0.71 *$ \\
\hline lpc & $11.27 \pm 1.57$ & $11.78 \pm 0.09 *$ & $11.65 \pm 0.78$ & $10.79 \pm 1.01$ \\
\hline $1 \mathrm{P}$ & $19.10 \pm$ & $17.80 \pm 0$ & 19.29 & $18.89 \pm 1.05$ \\
\hline IV & $15.69=$ & $14.56 \pm 0.07^{*}$ & $16.00 \pm 1.18$ & $15.82 \pm 0.82$ \\
\hline $\mathrm{hD}$ & $22.90 \pm 1.61$ & $21.10 \pm 0.15^{*}$ & $23.16 \pm 1.06$ & $23.16 \pm 1.58$ \\
\hline hA & $15.91 \pm$ & $14.30 \pm 0.09 *)$ & $16.18 \pm 0.81$ & $14.64 \pm 2.15^{*}$ \\
\hline $1 \mathrm{D}_{\mathrm{bs}}$ & $9.23 \pm 1.36$ & - & $10.47 \pm 0.67 *$ & $9.62 \pm 0.82$ \\
\hline $1 A_{b s}$ & $34.88 \pm 3.06$ & - & $34.39 \pm 0.92$ & $35.73 \pm 1.31$ \\
\hline $\mathrm{P}-\mathrm{V}$ & $19.49 \pm 2.59$ & $18.55 \pm 0.12 *$ & $20.81 \pm 1.19^{*}$ & $18.64 \pm 1.46^{*}$ \\
\hline $\mathrm{V}-\mathrm{A}$ & $18.57 \pm 2.41$ & $17.26 \pm 0.13 *$ & $19.68 \pm 1.09 *$ & $18.42 \pm 1.45$ \\
\hline
\end{tabular}

* statistically significant differences in means $(P<0.05$, test for two means); $\bar{x}$, mean

in the caudal part of the vertebral column. The total number of vertebrae in fish from the subfamily Cyprininae never exceeds 48 (modal number 38-40), but in the subfamily Leuciscinae the range is wider: 33-61 (modal number 40-45). An important feature is the range of predorsal vertebrae which equals 9-14 and 10-19 in Cyprininae and Leuciscinae, respectively (Howes 1987).

In the sample of zope examined, the range of the total number of vertebrae amounted to 46-48 (47.38 mean).
A similar number, 47-48, was determined by Rolik (1985) and Rolik and Rembiszewski (1987). Populations of A. ballerus analysed by Krzykawski et al. $(1994,1996)$ are characterized by 41-48 vertebrae. Similar results (40-46) were stated by Žukov (1965). According to Kozhara et al. (1996) the mean value ranged from 46.74 to 47.69 . These authors analysed the variation of the vertebral numbers in seven cyprinid species, among others four species of the genus Abramis. The samples represented the main portion

Table 8

Comparison of selected meristic characters of zope, Abramis ballerus, with data available in literature

\begin{tabular}{|c|c|c|c|c|c|c|c|c|c|c|c|c|}
\hline $\begin{array}{l}\text { Water } \\
\text { body }\end{array}$ & \multicolumn{2}{|c|}{ Odra River } & \multicolumn{2}{|c|}{ Dniepr River } & \multicolumn{2}{|c|}{ Lake Dąbie } & \multicolumn{2}{|c|}{ Lake Dąbie } & \multicolumn{2}{|c|}{ Lake Dąbie } & \multicolumn{2}{|c|}{ Lake Dąbie } \\
\hline Author & \multicolumn{2}{|c|}{$\begin{array}{c}\text { Present study } \\
(2003)\end{array}$} & \multicolumn{2}{|c|}{$\begin{array}{l}\text { Žukov } \\
(1965)\end{array}$} & \multicolumn{2}{|c|}{$\begin{array}{c}\text { Kompowski } \\
(1971 a)\end{array}$} & \multicolumn{2}{|c|}{$\begin{array}{c}\text { Rolik } \\
(1985) \\
\end{array}$} & \multicolumn{2}{|c|}{$\begin{array}{l}\text { Krzykawski } \\
\text { et al.(1994) }\end{array}$} & \multicolumn{2}{|c|}{$\begin{array}{l}\text { Krzykawski } \\
\text { et al. (1996) }\end{array}$} \\
\hline Feature & range & $\bar{x}$ & range & $\bar{x}$ & range & $\bar{x}$ & range & $\bar{x}$ & range & $\bar{x}$ & range & $\bar{x}$ \\
\hline$D$ & $8-10$ & 8.43 & $7-9$ & 8.02 & $8-9$ & 8.07 & $7-8$ & 7.9 & 8 & 8.0 & 8 & 8.0 \\
\hline$A$ & $34-43$ & 37.7 & $35-42$ & 36.9 & $35-42$ & 38.1 & $34-44$ & 37.9 & $31-4$ & 36.9 & $31-4$ & 36.9 \\
\hline$P$ & $15-18$ & 16.3 & $14-7$ & 15.7 & - & - & $16-19$ & 17.3 & $14-18$ & 16.2 & $14-18$ & 16.2 \\
\hline$V$ & $7-9$ & 8.1 & $8-9$ & 8.0 & - & - & $7-9$ & 8.0 & 8 & 8.0 & 8 & 8.0 \\
\hline l.l. & $64-73$ & 69.9 & $65-73$ & 68.8 & $68-77$ & 73.0 & $63-76$ & 69.9 & $65-71$ & 70.0 & $67-74$ & 65.0 \\
\hline$V t$ & $46-48$ & 47.3 & $40-46$ & 43.5 & - & - & $47-48$ & 47.5 & $45-48$ & - & $41-48$ & - \\
\hline$P h F$. & $\begin{array}{l}5-5 \\
5-4 \\
\end{array}$ & - & $\begin{array}{l}5-5 \\
5-6\end{array}$ & - & $5-5$ & - & $\begin{array}{l}5-5 \\
5-4 \\
\end{array}$ & - & $\begin{array}{l}5-5 \\
5-4 \\
\end{array}$ & - & $\begin{array}{l}5-5 \\
5-4\end{array}$ & - \\
\hline
\end{tabular}




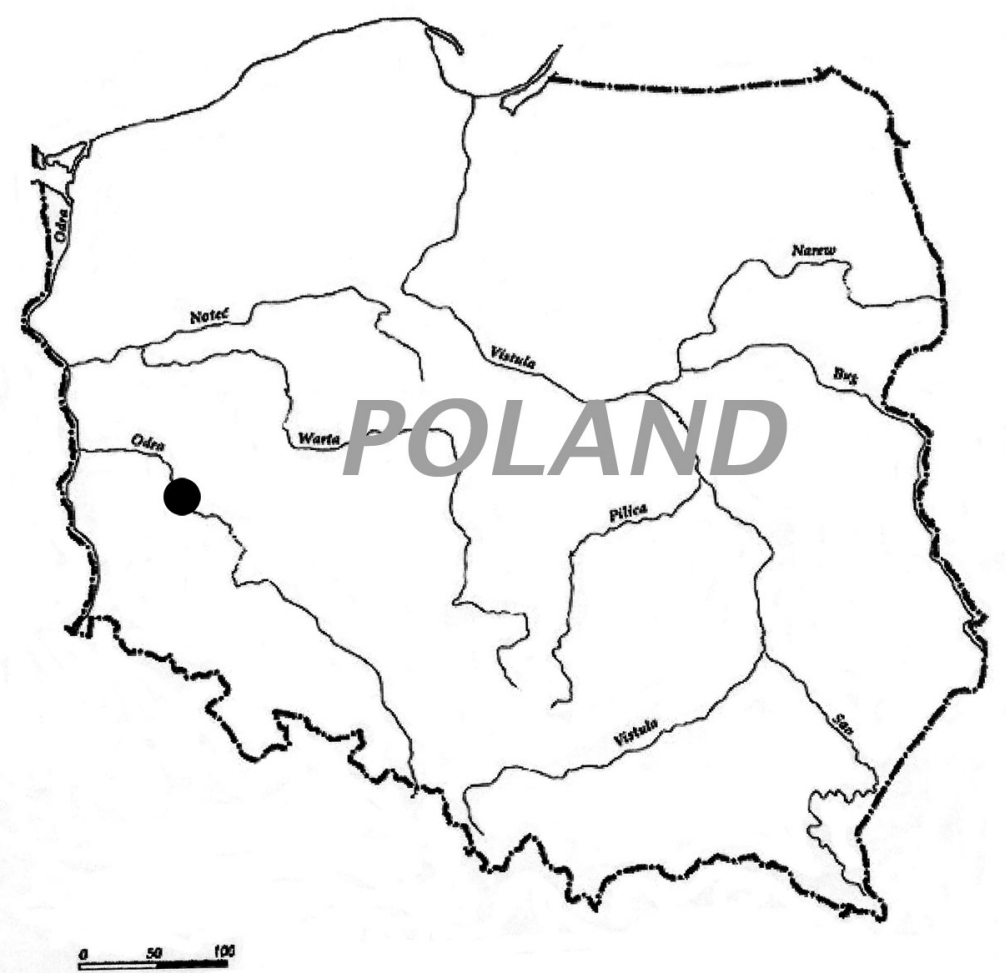

Fig. 1. The location of the sampling site of zope, Abramis ballerus, in the middle stretch of the Odra River
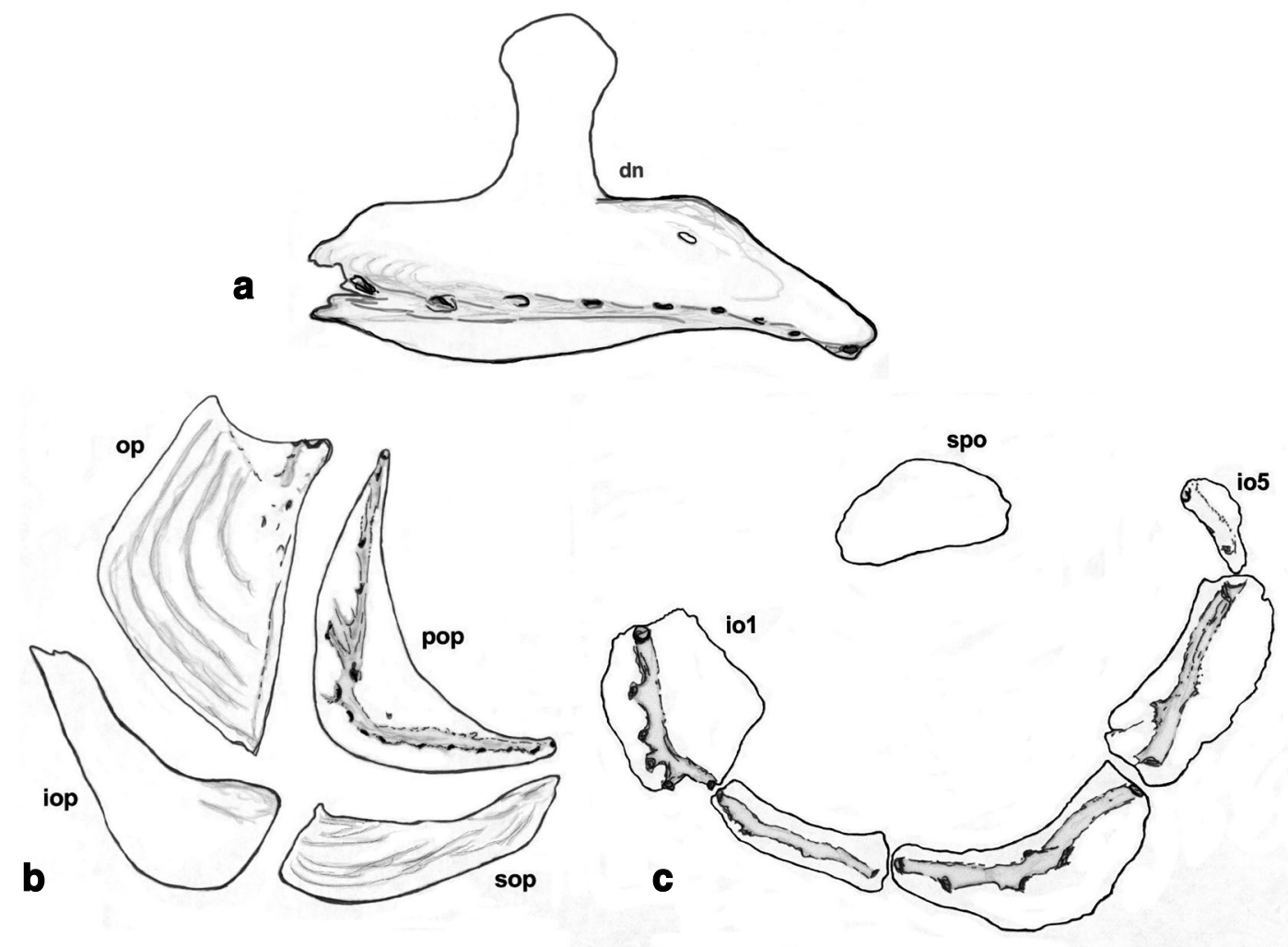

Fig. 2. Bones of the visceorocranium of zope, Abramis ballerus, from the middle stretch of the Odra River (291.6 mm in SL) with pores of the sensory cephalic canals. Fig. 2a. Dental (dn) (Orig. J. Szlachciak). Fig. 2b. Opercular bones (iop, interoperculum; op, operculum; pop, preoperculum; sop, suboperculum). Fig. 2c. Circumorbitals (io, infraorbitals; spo, supraorbital) 
of its range within the former USSR. It has been determined that in cyprinid species the number of vertebrae decreased southwards. Kožara et al. (1999) proved that fish in lakes tend to have more vertebrae than in other types of water bodies, even at the same latitude.

There are still relatively few data on the morphology of the lateral system of cyprinids. Hensel (1978) investigated morphology of the lateral system in representatives of the genera Abramis, Blicca, and Vimba, on the material from the Danube River. Mironovskij (1988) determined the number of bone pores in: preoperculum, operculum, dental, frontal, and parietal for some A. ballerus populations collected in different parts of the Volga River in the Caspian region.

No data are available on the variability of the abovementioned characters of the zope populations in Poland.

The extent of lateral system development in the representatives of the genera Abramis, Blicca, and Vimba is most likely associated with the fish's lifestyle and habitat. In A. ballerus, which is planktivorous species, there are more neuromasts in the operculo-mandibular canal. The benthofagous species, Vimba vimba and A. sapa show fewer neuromasts in the same canal. Zope had the most complete canal system (Hensel 1978).

A lower number of pores represents a primitive state for this character in the subfamily Leuciscinae, to which the genus Abramis belongs, whereas a higher number is a derived feature (Bogutskaâ 1988, 1990).

Mironovskij (1988) stated that the characteristics and the level of variability in the species under study were determined largely by their ecology rather than phylogenetic relations. A decrease in the number of openings on seismosensory canals was observed in species living in brackish waters.

According to Hensel (1978) the most specialized phyletic line is represented by A. ballerus and A. sapa.

\section{ACKNOWLEDGEMENT}

The presently reported study was supported by grant No. 0208.805 from the University of Warmia and Mazury in Olsztyn.

\section{REFERENCES}

Aleksandrova T.N. 1966. O since Vedlozera. [About the zope from Vedlozero.] Trudy karel'skogo otdeleniâ GosNIORH 4 : 148-152. [In Russian.]

Boguckaâ N.G. [Bogutskaya N.G.] 1988. Topografiâ kanalov sejsmosensornoj sistemy karpovyh ryb podsemejstv Leuciscinae, Xenocyprininae i Cultrinae. [Canal topography of the seismosensory system in carpian fishes of subfamilies Leuciscinae, Xenocyprininae and Cultrinae.] Voprosy ihtiologii [Voprosy ikhtiologii] 28: 367-382. [In Russian.]

Boguckaâ N.G. [Bogutskaya N.G.] 1990. Morfologičeskie osnovy sistemy karpovyh ryb podsemejstva el'covyh (Leuciscinae, Cyprinidae). Soobŝenie 2. [Morphological foundations of the systematics of cyprinids of the subfamily Leuciscinae (Cyprinidae) Part 2.] Voprosy ihtiologii [Voprosy ikhtiologii] 30: 920-933. [In Russian.]
Brylińska M. (ed.) 2000. Ryby słodkowodne Polski. [The freshwater fishes of Poland.] PWN, Warszawa. [In Polish.]

Dunn J.R. 1983. The utility of developmental osteology in taxonomic and systematic studies of teleost larvae: a review. Deptartment of Commerce, National Oceanic and Atmospheric Administration, National Marine Fisheries Service, Rockville, MD

Durand J.D., Tsigenopouols C.S., Ünlü E., Berrebi P. 2002. Phylogeny and biogeography of the subfamily Cyprinidae in the Middle East inferred from cytochrome b DNA - evolutionary significance of this region. Molecular Phylogenetics and Evolution 22: 91-100.

Gąsowska M. 1980. Osteological and morphological evidence for lack of close affinity between the genera Abramis Cuv. and Notemigonus Raf. (Pisces, Cyprinidae). Annales Zoologici 35: 194-201.

Hensel K. 1978. Morphology of lateral-line canal system of the genera Abramis, Blicca and Vimba with regards to their ecology and systematic position. Acta Universitatis Carolinae, Biologica 12: 105-149.

Howes G.J. 1987. The phylogenetic position of the Yugoslavian cyprinid fish genus Aulopyge (Heckel 1841) with an appraisal of the genus Barbus Cuvier \& Cloquet 1816 and the subfamily Cyprininae. Bulletin of the British Museum (Natural History), Zoology 52(5):165-196.

Howes G.J. 1991. Systematics and biogeography: an overview. pp. 1-33. In: Winfield I.J., Nelson J.S. (eds.) Cyprinid fishes, systematic, biology and exploitation. Chapman and Hall, London.

Kompowski A. 1971a. Badania nad rozpiórem Abramis ballerus (L.) z jeziora Dąbie. [Studies on zope, Abramis ballerus (L.), from Lake Dąbie.] Zeszyty Naukowe Wyższej Szkoły Rolniczej w Szczecinie 35: 35-51. [In Polish.]

Kompowski A. 1971b. Pokarm rozpióra Abramis ballerus (L.) z jeziora Dąbie. [Food of zope, Abramis ballerus (L.), from Lake Dąbie.] Zeszyty NaukoweWyższej Szkoły Rolniczej w Szczecinie 35: 53-68. [In Polish.]

Kompowski A. 1991. Catches and growth rate of Abramis ballerus (L., 1758) from Lake Dąbie and the Firth of Szczecin. Acta Ichthyologica et Piscatoria 21(2): 17-28.

Kožara A.V., Izûmov Û.G., Kas'ânov A.N., Zeleneckij N.M. [Kozhara A.V., Izyumov Yu.G., Kas'yanov A.N., Zelenetskiy N.M.] 1999. Zavisimost' čisla pozvonkov u presnovodnyh ryb ot tipa vodoema. [Dependence of the vertebral numbers on water body type in fresh-water fish.] Voprosy ihtiologii [Voprosy ikhtiologii] 39: 173-181. [In Russian.]

Kozara A.V., Izyumov Yu.G., Kas'yanov A.N., 1996. General and geographic variation of the vertebral numbers in some freshwater fish. Journal of Ichthyology 36: 222-237.

Krzykawski S., Gawliński L. 1986. Characteristic of lower pharyngeal arches and first gill arch of some Cyprynidae fish present in Dąbie Lake and Szczecin Firth as an additional criterion for systematic classification. Acta Ichthyologica et Piscatoria 16 (2): 23-32.

Krzykawski S., Banik K., Więcaszek B., Antoszek A. 1994. Morfometria rozpióra A. ballerus (L.) z jeziora Dąbie. 
[Morphometry of blue bream A. ballerus (L.) from the Lake Dąbie.] pp. 218-221. In: Furowicz A., Borowiec S., Ramisz A., Stachak S., Winnicki A. (eds.) Wkład nauk rolniczych w rozwój gospodarczy Pomorza Zachodniego. Materiały Sesji Naukowej. Wydawnictwo Akademii Rolniczej w Szczecinie. [In Polish.]

Krzykawski S., Banik K., Antoszek A. 1996. Biometric characters of the blue bream Abramis ballerus (L.) (Cyprinidae) from Lake Dąbie. Acta Ichthyologica et Piscatoria 27 (2): 63-75.

Mironovskij A.N. [Mironovskiy A.N.] 1988. O geografičeskoj izmienčivosti karpovyh ryb: osobennosti mikroêvolûcii populâcij del'tovo-êstuarnyh učastkov. [On the geographical variation of cyprinid fishes: the features of microevolution of fish populations in deltaic and estuarine zones.] Zoologičeskij Žurnal [Zoologicheskiy Zhurnal] 76: 1013-1023. [In Russian.]

Nelson J. 1994. Fishes of the world. John Wiley and Sons, New York.

Rolik H. 1985. Abramis ballerus (L.) i Pelecus cultratus (L.) (Pisces, Cyprinidae) w Polsce. [Abramis ballerus (L.) and Pelecus cultratus (L.) (Pisces, Cyprinidae) in Poland.] Fragmenta Faunistica 29 (9): 121-126. [In Polish.]

Rolik H., Rembiszewski M.J. 1987. Ryby i kragłouste. [Fishes and cyclostomes.] Polskie Towarzystwo Hydrobiologiczne, PWN, Warszawa. [In Polish.]

Strauss R.E., Bond C.E. 1990. Taxonomic methods: morphology. pp. 109-140. In: Schreck C.B., Moyle P.B. (eds)
Methods for fish biology. American Fisheries Society, Bethesda, MD.

Tadajewska M. 1980. Cechy merystyczne i biometryczne krąia - Blicca bjoerkna (L.) z Zalewu Wiślanego. [Meristic and biometric features of white bream, Blicca bjoerkna (L.), from the Vistula Lagoon.] Zeszyty Naukowe Akademii Rolniczo-Technicznej w Olsztynie 10: 182-192. [In Polish.]

Tadajewska M. 2000. Krąp. [Zope.] In: Brylińska M. (ed.) Ryby słodkowodne Polski. [The freshwater fishes of Poland.] PWN, Warszawa. [In Polish.]

Tåning A.V. 1950. Influence of the environment on number of vertebrae in teleostean fishes. Nature 165 (4184): 28.

Wierzbicka J. 1977. An attempt to explain affinities between Blicca bjoerkna (L.), Abramis brama (L.) and A. ballerus (L.) on the grounds of their parasitic fauna. Acta Ichthyologica et Piscatoria 7 (1): 3-13.

Vladykov V.D. 1934. Environmental and taxonomic characters of fishes. Biological Board of Canada. Royal Canadian Institute 43, 20 (1): 99-140.

Žukov P.I. [Zhukov P.I.] 1965. Ryby Belorussii. [Fishes of Byelorussia.] Izdatel'stvo Nauka i Tehnika, Minsk. [In Russian.]

Received: 27 July 2005 Accepted: 24 November 2005 